\title{
複数公共事業によるまちづくりプロジェクト・マネジ メントにおける日向市デザイン会議の役割と機能評価
}

\section{FUNCTIONAL EVALUATION OF HYUGA-CITY URBAN DESIGN COMMITTEE FOR PLURAL PUBLIC PROJECTS MANAGEMENT}

\author{
辻 喜彦 $^{1} \cdot$ 吉武 哲信 ${ }^{2} \cdot$ 出口 $\quad$ 近士 ${ }^{3}$ \\ 1学士（工学）＼cjkstart宮崎大学大学院博士後期課程農学工学総合研究科 (E-mail:y-tsuji@atelier74.co.jp) \\ 2 博士（工学）＼cjkstart宮崎大学工学部土木環境工学科准教授（E-mail: t.yoshi@cc.miyazaki-u.ac.jp) \\ 3 工博 宮崎大学工学部土木環境工学科准教授 (E-mail: deguchi@cc.miyazaki-u.ac.jp)
}

\begin{abstract}
まちづくりや地域再生においては複数の事業を組み合わせて良質な社会基盤整備を目指すことが多いが, それを実現するためには, 個別事業を相互連携させるとともに, 市民の公共空間の利活用を促して新たな 地域価值を創造していくことが必要で，そのためのマネジメント技術が不可欠である.

本論は, 宮崎県日向市駅周辺のまちづくり事業のために設置された「日向市都市デザイン会議」を事例 として，これが果たした複数の公共事業を総括するマネジメントの有効性について考察したものである.
\end{abstract}

キーワード : 複数プロジェクト・マネジメント. 地域再生事業. ソーシャルキャピタル

\section{1. はじめに}

\section{1. 研究の背景と目的}

2003年(平成15年)に「美しい国づくり政策大綱」の策 定以来，社会資本整備において地域価值を向上させ，地 域住民に豊かな暮らしをもたらし，後世への資産となる ような景観に配慮した良質な社会基盤整備が求められて いる. また，2006年(平成16年)には中心市街地活性化の ための「まちづくり三法」が見直し・改訂されており, 特に中心市街地の衰退が著しい地方都市においては, 実 効性を伴った地域再生事業の推進が期待されている1).

地域再生の多くは複数の事業の組み合わせによって実 施されており，その中で良質な社会基盤整備を実現する ためには，個別事業の枠を越えて地域再生プロジェクト に関わる関係者を相互協力させるプロジェクト・マネジ メントが不可欠である゙2. 加えて中心市街地のにぎわい を再生するためには, 公共事業による良質な社会基盤整 備のみならず，整備後の施設を有効かつ持続的に活用し ていく市民や市民団体の参画と活動も不可欠であり，そ のための市民の「信頼関係やネットワーク」(ソーシャル キャピタル(以下，SCと記す)を醸成することが重要であ るとの指摘もある ${ }^{3)}$. SCはPutnamによれば, 「人々の協調 活動を活発にすることによって社会の効率性を高める事 のできる信頼・規範・ネットワークといった社会の特徴」 とされている4).

以上の指摘は，地域再生においては，1)地域の将来像 と実現化手法等を明確化し，その具現化のために複数の プロジェクト(公共事業)を始動させること, 2)併せて市民
の公共空間の利活用を促して新たな地域価值を創造して いくようなプロジェクトー結びつけること，3)それら複 数のプロジェクトを有機的に連携させ, 地域再生のため のマネジメント・システムとして総合的・統合的に監 理・推進されることの必要性を示しているといえよう。

ここで公共事業におけるマネジメントに関する従来の 研究を見れば, 特定施設整備(モノづくり)において, 設 計から施工段階までを対象として効率的にプロジェクト を推進するためのコンストラクション・マネジメント (CM)や, 改正中心市街地活性化法に基づき地域社会の機 能を効率化させるエリア・マネジメント(AM)の観点から の研究は多(5), 6). ところで, 「エリアマネジメント推進 マニュアル」ブにおいは, 中心市街地活性へ向けて, 開 発だけでなく維持管理・運営するAMの取組みが重要で あるとしている. しかし，AMの活動要素に公共空間の 整備は含まれておらず, 活動組織は, 地域・事業者・地 権者等主体の地域づくりに限定されている. また地域組 織と行政との連携手法については, 社会的ストックとし ての公共施設の維持管理方法等が中心となっている.

一方, 都心域での都市基盤事業推進やマネジメントの 枠組みについての東海林らの研究 8 )では, 施設整備後の管

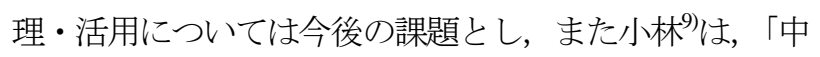
活協議会」の評価を行っているが, 商工会議所中心の組 織体制においては社会基盤整備との連携や人材育成が課 題であるとしている.これについては小林も「中心市街 地の再生・活性化は中心商業の活性化という色彩があま りにも強いため, 多くの地方都市では成果を上げるに至 っていない」 ${ }^{10)}$ と指摘している. 
本論文が対象とするような地方都市での地域再生にお いては, 街路事業や特定商業集積事業など主体の異なる 複数プロジェクトを同時併行的かつ面的に実施すること が求められ, さらには良質な社会基盤の形成, 持続性一 向けたSC醸成も重要課題となっている. しかし, 以上を 踏まえると, これらの要請に対して社会基盤整備の計画 段階から整備後の管理・活用まで積極的かつ一貫して対 応するための手法については, 殆じ研究がなされていな いと言えよう。

このような中で，宮崎県日向市においては中心市街地 再生を目標とし，市民参画のもとに良質な都市デザイン を実践するまちづくりが展開されている. 本論は, 日向 市の地域再生プロジェクトで設置された「日向市都市デ ザイン会議(以下，D会議と記す)」を対象として, これが 果たした複数公共プロジェクトを総合・統合するマネジ メント・システムとしての機能および公共事業を契機と して，市民の公共空間の利活用につなげていくことを意 図したSC醸成の支援機能について検証・考察するもので ある.

具体的には, D会議について次の3つの機能を評価する. 機能- 1 : 地域再生をめざしたまちづくり目標像を明確化 し, その具現化のための戦略の立案機能

機能 -2 : 複数の公共プロジェクトの総合・統合機能 機能-3:SC醸成を意図した市民の公共空間の利活用につ なげる活動支援機能

\section{2. 評価の枠組み}

Table1は本論におけるD会議の機能についての評価の 枠組みであり, 地域再生のための機能, 評価, 検証デー タの内容を示している. 具体的には, 機能-1に対しては, 目標像へ向けた実現プロセスや目標像へ向けて複数事業 を連結させたプロセス, 機能-2に対しては, 複数事業の 関係者相互や事業主体と市民団体等との連携体制の構築 プロセス, 機能-3に対しては, イベント開催数および参 加者数やアンケート調查による駅周辺地区に対する市民 の参画意識等を各々評価指標とする. そしてこれらの評 価を，D会議が果たしてきた機能を会議規約や会議記録 11),12）の整理，分析から追跡することによって評価する. そして以上を踏まえた上で, 地域の将来目標像を描き,
実現化戦略を立案し, 複数の公共事業を総合的・統合的 に管理・推進し市民の公共空間利活用につなげる一体的 な取り組みによって地域価值の再生創造をめざすマネジ メント・システムとしてD会議の担った役割・機能の有効 性を確認するものである.

\section{2. 日向プロジェクトの概要と D 会議の機能}

\section{1. 日向プロジェクトの概要}

日向市駅周辺地区における地域再生プロジェクトの概 要, 変遷とD会議に付託された機能を事業記録書、関連 資料等11), 12)から以下に整理する。

日向市は宮崎県北部に位置し, その中心市街地は古く から日向および耳川上流部である入郷圈域の立関口の役 割を担い，広域行政および広域商業機能の集積地として 発展した. しかし1990年代(平成元年)以降, 中心市街地 の衰退が顕著となり抜本的な都市構造改革が主要な課題 となった. このため, 日向市は1997年(平成9年)に「日向 市駅周辺まちづくり委員会」を設置し, 日向市駅周辺の 既成市街地を対象に「街なかに賑わいと活気があふれる 木を活かしたまちづくり」を計画コンセプトとした街な か魅力再生が検討された. その後, 中心市街地法(1998 年6月)成立とともに, 複数のまちづくり事業を総合的, 同時一体的に進める“日向プロジェクト”がスタートし， 市民, 商店主, 商工会議所やまちづくり団体等による 官民協働の「議論・合意形成の場」となる「日向市街な か魅力拠点整備検討委員会 (平成10年〜平成12年)」が設 置された ${ }^{11), 12)}$.

これとほぼ同時期に, 学識経験者(都市計画・土木・ 建築), 事業者(宮崎県都市計画課長・日向市建設部長 · JR九州(施設・建築部長))による “協議・調整・協働の場” として，まず平成10年に「鉄道高架・駅舎デザイン検討 委員会(平成10年〜平成12年)」が発足し, 基本構想がさ れ, 鉄道高架事業についての県・市・JRの三者協定締結 後, 平成13年からは「日向地区・都市デザイン会議(平成 13年〜現在まで)」に名称変更して宮崎県都市計画課と日 向市市街地整備課の共同所管された. そして, その下に, 都市計画, 土木設計, プロダクトデザイン, 建築設計等

Table 1 D 会議の機能評価の枠組み

\begin{tabular}{|c|c|c|c|}
\hline $\begin{array}{l}\text { 評価 } \\
\text { する } \\
\text { 機能 }\end{array}$ & $\begin{array}{l}\text { 1) 公共プロジェクトの,目標像の明確化と } \\
\text { その具現化への戦略立案 }\end{array}$ & $\begin{array}{l}\text { 2）複数の公共プロジェクト事業の総合· } \\
\text { 統合 }\end{array}$ & $\begin{array}{l}\text { 3） SC釀成を意識して市民の公共空間の利 } \\
\text { 活用に繋かる活動支援 }\end{array}$ \\
\hline $\begin{array}{l}\text { 評価 } \\
\text { 内容 }\end{array}$ & $\begin{array}{l}\text { ·目標像へ向けたた実現プロセス } \\
\cdot \text { 目標像へ向けナた複数事業の連結プロセス }\end{array}$ & $\begin{array}{l}\cdot \text { ·複数事業の関係者相互の連携 } \\
\text { 事業主体と市民团体等との連携 }\end{array}$ & $\begin{array}{l}\text { ·イベント開催数及び集客数の推移 } \\
\text { ·プロジェクト育加した市民意識 } \\
\text { 変化 }\end{array}$ \\
\hline 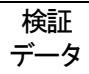 & \multicolumn{3}{|c|}{ ·会議記録 ${ }^{11)}$, 事業記録書 ${ }^{12}$, 会議設置要綱 ${ }^{13}$ ，アンケート調査結果等より整理·確認 } \\
\hline
\end{tabular}


の専門家チームによるワーキンググループ $(\mathrm{WG})$ が編成 され，関係機関，関係者の相互協力体制のもとで事業化 が進められることとなった ${ }^{11), 12)}$.

日向プロジェクトは大きく3つのプロジェクトから 構成される(Fig.1). これらを以下に概説する.

1)JR日向市駅を中心とした1.67km区間「連続立体交差事 業(以下，連立事業)」(宮崎県事業).

2)駅周辺地区(17.6ha)「都市再生土地区画整理事業(以下, 区画整理事業)」(日向市事業).

3)駅周辺中心商業街区(24.0ha)「中心商業地区再生事業 (特定高度集積整備事業: 以下, 商業集積事業)」(民間事業).

以上のように本プロジェクトは，連立事業に伴う区画 整理事業導入による駅周辺中心地区の再生に, 商業集積 事業をも組み合わせた「三位一体」事業である.さらに 市民発意によるイベント開催や官民協働の街づかい，街 育て等の取り組みと連携している点に特長がある(Fig.1).

なお，地場産杉材を活用した新駅舎を新たな日向のシ ンボルとしたハード面整備は，2006年(平成18年) 12月に 新日向市駅開業，鉄道高架切替えおよび東口駅前広場完 成, および2008年(平成20年) 3月の西口駅前広場完成, および2009年(平成21年)3月駅前交流広場完成によって 第1期の整備を完了したところである ${ }^{11,12)}$. また良質な公 共空間(鉄道高架下，駅前広場や街区中庭空間)は市民主 体の祭やイベントに利活用され, 後述のように開催回数, 集客数とも年々増加し ${ }^{11)},{ }^{12}$, 街なかに賑わいが戻りつつ ある.

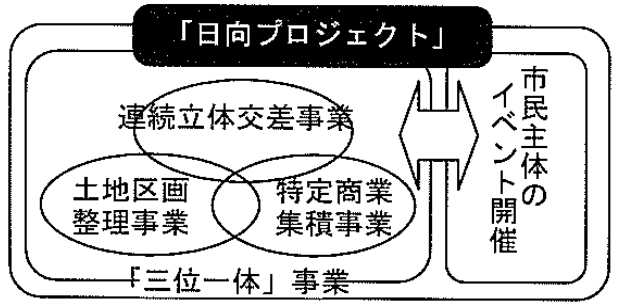

Fig.1「三位一体」日向プロジェクトの概念図

\section{2. $\mathrm{D}$ 会議の設置と役割}

\section{（1） D 会議設置の目的}

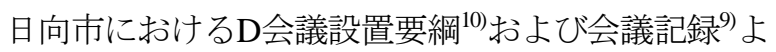
りD会議に付託された機能と役割について以下に整理す る.

日向市による会議設置要綱第2条(目的)において，「日 豊本線日向地区連続立体交差事業 (以下「事業」と記す。) 並びに日向市駅周辺整備の推進に資寸るため, 様々な情 報及び意見の交換を行うことを目的とする.」と規程され ている.さらに第3条(所掌事項)において「会議は，(1) 交通結節機能をより向上させるための都市施設整備に関 する事項. (2)事業施行に伴う高架下等の土地利用に関す
る事項. (3)その他事業の目的達成のための必要な事項. とされている.

つまり, 宮崎県, 日向市およびJR九州に対して駅周辺 施設の景観デザインを提案することを目的とするD会議 は, 日向市駅周辺整備といらプロジェクトの目的達成の ために，初期段階で設定された計画および景観デザイン コンセプトを長期にわたり変容させることなくプロジェ クトを推進することを目的としている. このため，1)鉄 道高架および周辺土地利用に関するハード面整備のマネ ジメントと，2)プロジェクト進捗等に関する情報公開お よび意見交換を通じて行政関係者および市民レベルでプ ロジェクトの目標像を共有化し, 横断的な取り組みを促 進させるソフト面マネジメントの両面を一体的にプログ ラムする役割が発足当初から求められた. D会議は行政 と事業者だけでなく, 学識経験者, 専門家を含めてプロ ジェクトを部外から監理する組織とし, 県, 市, JRおよ び市民との連携を図ることが重要であることが会議準備 段階で認識され，このために宮崎県と日向市が共同でD 会議を設置した.

\section{（2）D会議に期待された機能と役割}

従来の公共事業は個別に縦割り所管されるために，同 じ対象エリア内にあっても十分に相互のデザイン調整等 が図られずに進められることが多い.このことが一定エ リア内の景観デザインの統一感, 一体感を実現する上で の課題と指摘されている ${ }^{11)}$. 特に連立事業の場合には, 事業主体と鉄道事業者，市民等の相互意識，組織体制の 違いや長年の慣習等から連携体制が十分に築けないため に，駅が街に対して閉ざされた空間になることが多く， 街の賑わい再生拠点に至らないことが課題となっていた 12). そのため次の3点がD会議に付託された ${ }^{13)}$.

a) 地区将来像の明確化 : 異なる事業主体が同じベクトル 目標像)のもとで “三位一体”のプログラムを推進す るために, 駅を中心とする生活文化交流拠点の創出と 賑わい再生をまちづくり目標像として明確化し, 事業 者および市民間での共有化を図っていくこと.

b) 複数プロジェクトの調整 : Fig.2に示すように設計デザ インワーキングチームの業務を介して, 関連する複数 の個別プロジェクト(鉄道高架構造物, 駅舎建築, 駅 前広場, 交流広場, 橋梁, 街路, 街区内建物等)を協 議項目として, 賑わい再生という目標実現の視点から 各事業間の連携，調整等を行うことにより，“空間的 一貫性”を持った地区デザインを実現していくこと.

c) 関係者の合意形成 : 関係事業担当者間の意識の共有化 による, 議論と合意形成および対象エリアにおける事 業主体, 関係者, 市民グループ, 市民等の合意形成. なお，a)〜c)についてデザインの観点から補足してお く. 一般に, 長期に亘り事業を進める場合, 一連のプ 


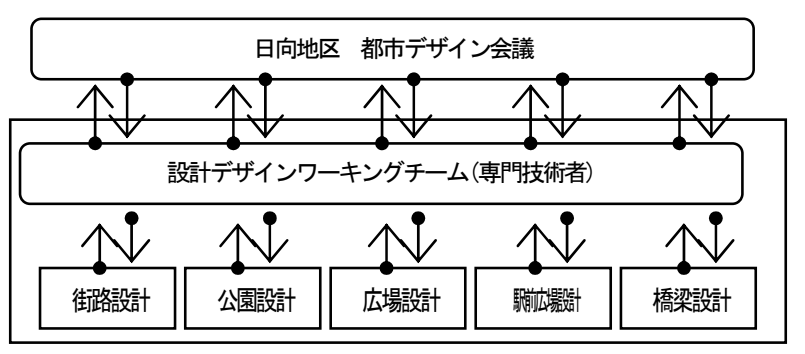

Fig.2 複数事業の統括と合意形成の場づくり

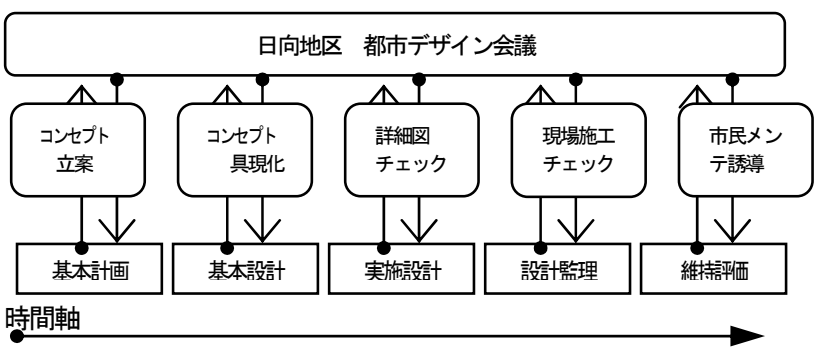

Fig.3 プロジェクトの一貫性の確呆

ロセスにおいて行政担当者の異動や担当部局の移行, 首長交代等による組織体制の変更が起きる例が多く, また業務を受託する設計者(コンサルタント等)も調査, 予備設計, 詳細設計の業務毎に異なることが多いため に, 計画段階で描かれ合意形成されたデザイン設計案 が竣工時には全く異質なものに変容する例が多いとの 指摘がある ${ }^{14)}$

これに対して，D会議ではFig.3に示すように, 計画段 階のデザインコンセプトを基本設計〜実施設計〜施工に 継承させる方式がとられた. 寸なわちD会議の仕組みに は, 行政担当者や設計者に対して監修, 指導, アドバイ ス寸る役割と機能を確保することで，事業担当者等の異 動や事業計画(予算や工期等)の変更等にも柔軟に対応し, 計画から竣工まで一貫性のある良質な空間デザインを実 現するというマネジメント機能が設定されたといえる.

\section{3. 日向 D 会議が果たした機能・役割についての検証}

\section{1. $\mathrm{D}$ 会議の活動実績}

日向市におけるD会議の会議録11)および事業記録 ${ }^{12)}$ り，プロジェクトの進捗に伴って各ステージにおいてD 会議が直面した課題とそれに対する対応方法, 役割につ いて以下に整理する.

本プロジェクトの辿ってきたプロセスを連続立体交差 事業の「基本構想・計画」「基本設計」「実施設計」「施工 監理」の時系列で整理すると，4つのステージ(段階)に区 分できる. 以下に各ステージにおけるD会議の実践・実 績を整理し，プロジェクトの進捗に伴い直面した課題等 に対して，D会議が実践したプロジェクト・マネジメン 卜(以下，Project Management: PMと略記する)の対応方法 (目標像の明確化, 複数事業の総合・統合化による一貫性
の確保，SCの醸成)について分析する.

\section{1) 第1ステージ(立ち上げ期 : 1996 1998年) (1) $\mathrm{D}$ 会議の実践内容}

第 1 ステージにおいて, 学識者および宮崎県・日向市・ JR九州の事業関係者による「鉄道高架・駅舎デザイン検 討委員会(都市デザイン会議の前身組織)」および市民主 体による「街なか魅力拠点整備検討委員会」が設置され た.

D会議は，事業関係者間(県とJR，県と市等)が個別で協 議する駅周辺地区の基本的なグランドデザインについて 議論する役割を担い(プログラム戦略の策定), 地区将来 像および鉄道高架・駅舎デザインの基本コンセプトを明 確化した. つまり，D会議の設置によって設計意図(複数 事業の連携)を実現するために，複数事業関係者が“一同 に会して議論できる場”が構築され, プロジェクトが始動 した.

\section{2)第2ステージ(初期段階 : 1999年 2001年) (1) $\mathrm{D}$ 会議の実践内容}

第2ステージでは, 始動したプロジェクトを軌道へ乗せ ることと，事業担当者間でとりまとめられた基本計画の 方向性を一般市民に公開して広く合意形成を図り，プロ ジェクトを推進していくことが求められた.このためD 会議は, 下部組織として県, 市, JR九州, 設計者, 木材 関係者等による「木材利活用ワーキング(木材WG)」を設 置し，木造大屋根の駅舎建設を実現するための地場産杉 材利用の技術的検討之駅舎, 駅前広場, 商業街区におけ る複数関連事業を繋ぐ共通素材としての木材利活用のた めの連携体制づくりを行った. これに呼応して区画整理 事業地内の一体的整備を図るための「日向市駅周辺ふる さとの顔づくり委員会」が設置された(複数事業の連携).

この段階では，プロジェクトの時間的・空間的一貫性 を確保するために多くの苦労を費やした時期でもあった が，例えば，D会議を離脱しかけたJR九州に対して県市 各担当者は会議外でディスカッションを重ね，プロジェ クト継続のために積極的に対応することで難局を乗り越 える意思を何度も確認しあった．このようにしてまとめ られた計画案はシンポジウム等で公表され，市民からも 計画コンセプトおよび地域再生手法に対して支持を得て, 継続的な取り組み体制を確立した (複数プロジェクトの 統括および一貫性の確保).

またD会議において議論された基本構想・計画につい て日向市は毎年シンポジウムを開催し，市民一情報公開 する手法をとった．このシンポジウム等を通じて，本プ ロジェクトのテーマである「木を活かしたまちづくり」

「地場産材による新たなシンボルとなる新駅舎デザイ ン」「駅・広場・商業街区の一体的整備」等について市民 の賛同が得られ，担当者中心の事業から後述するイベン 卜開催のように一般市民，商業者や木材関係者等の参画 
を促した(SCの醉成).

\section{3)第3ステージ(展開期 : 2001年 2004年) (1) $\mathrm{D}$ 会議の実践内容}

第3ステージにおいては, 鉄道高架工事が起工され街の 姿が変貌し始めた。 関係者や市民の間に芽生えた目標意 識をより拡げることによって, 関係する複数事業の連携 を強めていくことが求められていた。 そのために行政担 当者は，一部整備された商業街区を活用したイベント開 催や小学生を対象とした課外授業等を企画運営し, D会 議委員はSC醸成の観点からそれらに積極的に参画した。 このことによって，D会議委員と一般市民との交流が生 まれ，一般市民等が自発的に参加する様々なイベント(街 なかハロウィンや土曜夜市等) やセミナー (街区毎の研 究会）等が開催されるようになり，プロジェクトへ多様 な人々が参加する契機となった (SCの醸成).

駅舎設計については，D会議委員がJR九州の設計担当 を支援する形で設計監修の立場で技術的なアドバイスを するとともに，木材WGの成果を受けて，風洞実験等を 行い, JR九州は実施設計の精度を高めた(プロジェクトの 一貫性の確保). また当該地区がふるさとの顔づくりモデ ル地区に指定されたことから, 駅周辺の建築ルールを検 討する「街並み景観づくり協議会」を設置し，D会議委 員もメンバーとなり，具体的な景観コントロールのため の地区計画策定に取り組んだ(複数事業の連携).

ちなみに2004年(平成15年)に開催されたまちづくり課 外授業(日向市活性化塾) は, 「デザイナーが主体となり, 行政, 企業, 学校, 市民が一体となって活動をしている 教育プログラムであり, (中略)その取組みには, 社会的 な意義がある. 何より, 参加した誰もが元気になってい る活動の成果そのものも評価できる」として評価され,

「富高小学校特別授業「移動式夢空間」はグッドデザイ ン賞(新領域デザイン部門) を受賞した.

\section{4)第4ステージ(熟成期 : 2005年〜2008年)}

\section{(1) $\mathrm{D}$ 会議の実践内容}

プロジェクトがスタートしてから約10年を迎える第4 ステージにおいては, 新駅開業へ向けて, 市民, 行政, 専門家による連携体制を強化することが求められていた.

県・市・JR九州の技術者および尃門家チームは，強度 実験等に基づく新技術(变断面湾曲集成材や外構用木材 処理等)の開発による木造駅舎設計・工事を実現し，1柱 式15mスパンの高架橋デザイン設計の技術的検討によっ て約1割のコストダウン等を実現した.また駅舎建設にあ たっては, 設計を監修したD会議委員の設計事務所が設 計監理を行い，関係者はホームページ上で工事進捗状況 を情報公開した(プロジェクトの一貫性の確保).

また前ステージで築かれた市民，行政，専門家の連携 体制をもとに, 完成する新駅舎や駅前広場の利活用や維 持管理体制を確立するためにD会議からの要請を受けて
県と市は共同で関連委員会となる「駅前広場等利活用委 員会(駅広委員会)」を設置し, 利活用についての議論を 積み重齐た. 駅広委員会には, D会議委員が委員長を務 め, 設計チームも参画し，施工現場の市民説明やバリア フリー対応の設計仕様やサイン類の色彩選定等について 検討している. また建築家であるD会議委員は, 駅周辺 街区における新築店舗等の建築アドバイスを行なうとと もに, 地元建築士会有志と共同て駅東市営駐車場管理棟 を設計するに至った(複数事業の連携，SCの醸成).

さらにプロジェクト第1期の完成となる新駅開業に先 立って, D会議および県・市担当者は駅舎見学ツアーや 高架ウォークラリー等のイベントを企画運営し, 市民の 参加を募った. この結果として, 2007年(平成18年)12月, 新駅開業時には市民約15,000人が集うイベントを企画, 開催，運営することができた(SCの醸成).

このような変遷を経て，2006年(平成18年)12月に新日 向市駅開業, 鉄道高架切替え, 東口駅前広場完成, およ び2008年(平成20年)3月に西口駅前広場が, 2009年(平成21 年)3月に駅前交流広場が完成した. そして野外ステージ 完成(2010年度予定)のグランドオープンへ向けて, 商業 者, 市民, 行政による街育て組織活動が活発化し, さら に建築士会による周辺街区の建築作法書等が市長へ提言 されたところである.

ちなみに新日向市駅については, 地元産木材を利用し, デザインが地域の都市計画に調和していることが評価さ れ，2007年10月に鉄道建築協会賞（鉄道建築協会主催） 作品部門で，国土交通省鉄道局長賞に選定され，2008年 10月1日には, 世界各国の鉄道関連の建築家やデザイナー で構成されるワトフォード会議の「ブルネル賞」最優秀 賞を国内で初めて受賞し, 地域の杉材を使い, 独特の建 築様式を取り入れた駅舎が世界で高い評価を受けた.こ れらは, 駅周辺のまちづくりと調和した駅舎デザインの 「空間的・時間的監理」の結果が評価されたものといえ よう.

\section{2. 目標像の実現化」に関してD会議の果たした役割}

地域再生のプログラム全体に与えられた使命に基づ いてまちづくり目標像(戦略)を設定し, それらを具現化 寸るための複数プロジェクトのシナリオを展開し, その 実現可能性を検討する機能に対して，D会議が対応した 内容をTable 2に整理する. Table 2の左から第1欄には事業 段階, 第2欄にはD会議が直面した課題, 第3闌には課題 を解決して目標像実現化のためにD会議が実施したマネ ジメント内容, 第5闌にはD会議からの要請·指示に基づ く関係者等の対応を整理した (第4闌は後述する).

第1ステージでは, 中心市街地活性化という目標像を 掲げ，その実現のために三位一体というプロジェクト戦 略を提示した. また複数事業を組合わせた駅周辺空間の 
Table 2 「目標像明確化・戦略立案」に関してD会議の果たした役割

\begin{tabular}{|c|c|c|c|c|}
\hline 事業段階 & D会議が直面した課題 & $\begin{array}{c}\text { D会議が実施したマネジメント } \\
\text { (議事録より) }\end{array}$ & $\begin{array}{c}\text { P2Mマネジメ } \\
\text { ント項目 }\end{array}$ & $\begin{array}{c}\mathrm{D} \text { 会議からの要請・指示に基づく対応 } \\
\text { (記録書より) }\end{array}$ \\
\hline \multirow{2}{*}{$\begin{array}{l}\text { 第1ステージ } \\
\text { 構想計画段階 } \\
\text { (1996 } \\
\text { 1998年) }\end{array}$} & $\begin{array}{l}\text { 県・市・JR各事業主体によ } \\
\text { る連携体制の確立 }\end{array}$ & $\begin{array}{l}\text { まちづくり将来像や事業計画を明確化 } \\
\text { し連携体制の必要性を提示した }\end{array}$ & $\begin{array}{l}\text { 戦略 } \\
\text { マネジメント }\end{array}$ & $\begin{array}{l}\text { 担当者間で各地の失敗事例を研究し,目標実 } \\
\text { 現のための体制づくりを検討した(県・市) }\end{array}$ \\
\hline & $\begin{array}{l}\text { 行政・市民・JRによる事業 } \\
\text { 化への合意形成手法の検討 }\end{array}$ & $\begin{array}{l}\text { 専門的議論 (デザ 仪WG)と市民協議 } \\
\text { (街なか委員会)の場設置を要請した }\end{array}$ & $\begin{array}{l}\text { 組織 } \\
\text { マネジメント }\end{array}$ & $\begin{array}{l}\text { デザインWGを立場の枠を越えた自由な議 } \\
\text { 論ができる場として設置した(県・市) }\end{array}$ \\
\hline \multirow{2}{*}{$\begin{array}{l}\text { 第2 ステージ } \\
\text { 基本設計段階 } \\
\text { (1999〜 } \\
\text { 2001年) }\end{array}$} & $\begin{array}{l}\text { 駅舎·高架構造物と駅前広場 } \\
\text { の一体的整備の検討 } \\
\end{array}$ & $\begin{array}{l}\text { 駅部の高架橋スパンの拡大による利便 } \\
\text { 性の高い駅広配置の実現を要請 }\end{array}$ & $\begin{array}{l}\text { 統括 } \\
\text { マネジメント } \\
\end{array}$ & $\begin{array}{l}\text { 標準設計外の高架構造設計によりコストダ } \\
\text { ウンを実現する一体的整備案提示(設計者) }\end{array}$ \\
\hline & $\begin{array}{l}\text { 駅舎への木材利用の実現化 } \\
\text { へ向けた検討 }\end{array}$ & $\begin{array}{l}\text { 駅舎への木材利活用へ向けての検討 } \\
\text { WGシステム構築を要請した }\end{array}$ & $\begin{array}{l}\text { 組織 } \\
\text { マネジメント }\end{array}$ & $\begin{array}{l}\text { 技術的検討を行う木材WGを設置した } \\
\text { (県·市・JR・不材関係者・設計者) }\end{array}$ \\
\hline \multirow{2}{*}{$\begin{array}{l}\text { 第3ステージ } \\
\text { 実施設計段階 } \\
\text { (2002〜 } \\
\text { 2004年) }\end{array}$} & $\begin{array}{l}\text { 駅舎と駅前空間の一体的整 } \\
\text { 備実現のための検討 }\end{array}$ & $\begin{array}{l}\text { 木を活かした街づくり実践のため } \\
\text { SFWGを共通仕様書検討を指示した }\end{array}$ & $\begin{array}{l}\text { 統括 } \\
\text { マネジメント }\end{array}$ & $\begin{array}{l}\text { 地区外郭の塩見橋整備において木を活かし } \\
\text { た街づくりの試行を重ねた(県·市・設計者) }\end{array}$ \\
\hline & $\begin{array}{l}\text { 市長交代によるD会議存続 } \\
\text { の危機への対応 }\end{array}$ & $\begin{array}{l}\text { ハード整備だけでなく,市民活動,周辺 } \\
\text { まちづく含めた議論の場としてD } \\
\text { 会議を機能させることとした }\end{array}$ & $\begin{array}{l}\text { 組織 } \\
\text { マネジメント }\end{array}$ & $\begin{array}{l}\text { 新市長へのまちづくり施策を説明し,会議継 } \\
\text { 続の重要性を訴えた(市担当者) }\end{array}$ \\
\hline \multirow{2}{*}{$\begin{array}{l}\text { 第4ステージ } \\
\text { 施工段階 } \\
\text { (2004〜 } \\
\text { 2008年) }\end{array}$} & $\begin{array}{l}\text { 駅周辺の民間建築デザイン } \\
\text { の誘導方法の検討 }\end{array}$ & $\begin{array}{l}\text { 建築士会とのWSを開催し,周辺地区の } \\
\text { 建築作法書づくりを提案した }\end{array}$ & $\begin{array}{l}\text { 統括 } \\
\text { マネジメント }\end{array}$ & $\begin{array}{l}\text { 市営駐車場の共同設計し,木材利用の実績を } \\
\text { 作った(市・設計者・建築士会) }\end{array}$ \\
\hline & $\begin{array}{l}\text { 県·市共同から市主催への移 } \\
\text { 行検討 }\end{array}$ & $\begin{array}{l}\text { 会議継続によって,県・市・JRの協力体 } \\
\text { 制を維持した }\end{array}$ & $\begin{array}{l}\text { 組織 } \\
\text { マネジメント }\end{array}$ & $\begin{array}{l}\text { 県出向職員が市事業担当として帰任するシ } \\
\text { ステムを作った(県・市) }\end{array}$ \\
\hline
\end{tabular}

Table 3 「複数プロジェクトの総合・統合」に関してD会議の果たした役割

\begin{tabular}{|c|c|c|c|c|}
\hline 事業段階 & D会議が直面した課題 & $\begin{array}{c}\mathrm{D} \text { 会議が実施したマネジメント } \\
\text { (議事録より) }\end{array}$ & $\begin{array}{l}\text { P2Mマネジメ } \\
\text { ント項目 }\end{array}$ & $\begin{array}{c}\mathrm{D} \text { 会議からの要請・指示に基づく対応 } \\
\text { (記録書より) }\end{array}$ \\
\hline \multirow{2}{*}{$\begin{array}{l}\text { 第1ステージ } \\
\text { 構想計画段階 } \\
\text { (1996〜 } \\
\text { 1998年) }\end{array}$} & $\begin{array}{l}\text { 県・市・JR各事業主体による } \\
\text { 連携体制の確立 }\end{array}$ & $\begin{array}{l}\text { まちづくり将来像や事業計画を明 } \\
\text { 確化し連携体制の必要性を提示し } \\
\text { た }\end{array}$ & $\begin{array}{l}\text { 統括 } \\
\text { マネジメント }\end{array}$ & $\begin{array}{l}\text { 担当者間で各地の失敗事例を研究し,目標実 } \\
\text { 現のための体制づくりを検討した(県・市) }\end{array}$ \\
\hline & $\begin{array}{l}\text { D会議からのJR離脱の危機へ } \\
\text { の対応 }\end{array}$ & $\begin{array}{l}\text { 離脱を望むJRに対する会議参加の } \\
\text { 要請を行った }\end{array}$ & $\begin{array}{l}\text { タイム } \\
\text { マネジメント }\end{array}$ & JRへの説得と要請を積み重ねた(県担当者) \\
\hline \multirow{2}{*}{$\begin{array}{l}\text { 第2ステージ } \\
\text { 基本設計段階 } \\
\text { (1999 } \\
\text { 2001年) }\end{array}$} & $\begin{array}{l}\text { 駅舎·高架構造物之駅前広場 } \\
\text { の一体的整備の検討 }\end{array}$ & $\begin{array}{l}\text { 駅部の高架橋スパンの拡大による } \\
\text { 利便性の高い駅広配置の実現を要 } \\
\text { 請 }\end{array}$ & $\begin{array}{l}\text { 統括 } \\
\text { マネジメント }\end{array}$ & $\begin{array}{l}\text { 標準設計外の高架構造設計によりコストダ } \\
\text { ウンを実現する一体的整備案提示(設計者) }\end{array}$ \\
\hline & $\begin{array}{l}\mathrm{D} \text { 会議からのJR離脱の危機へ } \\
\text { の対応 }\end{array}$ & $\begin{array}{l}\text { 設計者がJR監修の立場となること } \\
\text { でD会議での設計検討を継続させ } \\
\text { た }\end{array}$ & $\begin{array}{l}\text { タイム } \\
\text { マネジメント }\end{array}$ & $\begin{array}{l}\text { 駅舎設計の安全性確保と著作権についての } \\
\text { 協議を積み重ねた(県・JR) }\end{array}$ \\
\hline \multirow{2}{*}{$\begin{array}{l}\text { 第3ステージ } \\
\text { 実施設計段階 } \\
\text { (2002〜 } \\
\text { 2004年) }\end{array}$} & $\begin{array}{l}\text { 駅舎と駅前空間の一体的整備 } \\
\text { 実現のための検討 }\end{array}$ & $\begin{array}{l}\text { 木を活かした街づくり実践のため } \\
\text { SFWG設置,具体検討を指示した }\end{array}$ & $\begin{array}{l}\text { 統括 } \\
\text { マネジメント }\end{array}$ & $\begin{array}{l}\text { 地区外郭の塩見橋整備において木を活かし } \\
\text { た街づくりの試行を重ねた(県・市・設計者) }\end{array}$ \\
\hline & $\begin{array}{l}\text { 設計コンセプトの実施設計へ } \\
\text { の反映 }\end{array}$ & $\begin{array}{l}\text { デザイナーとコンサルの共同体制 } \\
\text { による駅広設計チームを編成した }\end{array}$ & $\begin{array}{l}\text { タイム } \\
\text { マネジメント }\end{array}$ & $\begin{array}{l}\text { 基本デザインに対する市民WSを開催し,関 } \\
\text { 係者間で整備イメージを共有化した }\end{array}$ \\
\hline \multirow{2}{*}{ 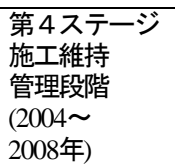 } & $\begin{array}{l}\text { 駅周辺の民間建築デザインの } \\
\text { 誘導方法の検討 }\end{array}$ & $\begin{array}{l}\text { 建築士会とのWSを開催し,周辺地区 } \\
\text { の建築作法書づくりを提案した }\end{array}$ & $\begin{array}{l}\text { 統括 } \\
\text { マネジメント }\end{array}$ & $\begin{array}{l}\text { 市営駐車場の共同設計し,木材利用の実績 } \\
\text { を作った(市・設計者・建築士会) }\end{array}$ \\
\hline & $\begin{array}{l}\text { 駅広空間の施工状況の確認と } \\
\text { 維持管理への対応 }\end{array}$ & $\begin{array}{l}\text { 設計監修とともに維持管理体制づ } \\
\text { くりを検討した }\end{array}$ & $\begin{array}{l}\text { タイム } \\
\text { マネジメント }\end{array}$ & $\begin{array}{l}\text { 利活用WGに参加した市民団体が主体的に } \\
\text { 維持管理を担える仕組みを構築した(市) }\end{array}$ \\
\hline
\end{tabular}

Table 4 「SC醸成を意図した市民等の活動支援」に関してD会議の果たした役割

\begin{tabular}{|c|c|c|c|c|}
\hline 事業段階 & $\begin{array}{l}\text { D会議が直面した } \\
\text { 課題 }\end{array}$ & $\begin{array}{c}\text { D会議が実施したマネジメント } \\
\text { (議事録より) }\end{array}$ & $\begin{array}{l}\text { P2Mマネジメ } \\
\text { ント項目 }\end{array}$ & $\begin{array}{c}\mathrm{D} \text { 会議からの要請・指示に基づく対応 } \\
\text { (記録書より) }\end{array}$ \\
\hline \multirow{2}{*}{$\begin{array}{l}\text { 第1ステージ } \\
\text { 構想計画段階 } \\
\text { (1996〜 } \\
\text { 1998年) }\end{array}$} & $\begin{array}{l}\text { 行政・市民·JRIによる事業化 } \\
\text { への合意形成手法の検討 }\end{array}$ & $\begin{array}{l}\text { 専門的議論 (デザ 代WG)と市民協議 } \\
\text { (街なか委員会)の場設置を要請した }\end{array}$ & $\begin{array}{l}\text { 組織 } \\
\text { マネジメント }\end{array}$ & $\begin{array}{l}\text { 立場の枠を越えた自由な議論ができる場と } \\
\text { してデザインWGを設置した(県・市) }\end{array}$ \\
\hline & 県 · 市担当者の連携体制確立 & $\begin{array}{l}\text { 県・市担当者に対して明確化な事業ビ } \\
\text { ジョンを提示し共有化を図った }\end{array}$ & $\begin{array}{l}\text { コミュニティ } \\
\text { マネジメント }\end{array}$ & $\begin{array}{l}\text { 市担当職員が県へ出向し事業を担当する実 } \\
\text { 績を作り,情報共有化を図った(県・市) }\end{array}$ \\
\hline \multirow{2}{*}{$\begin{array}{l}\text { 第2ステージ } \\
\text { 基本設計段階 } \\
\text { (1999〜 } \\
\text { 2001年) }\end{array}$} & $\begin{array}{l}\text { 駅舎への木材利用の実現化 } \\
\text { へ向けた検討 }\end{array}$ & $\begin{array}{l}\text { 駅舎への木材利活用へ向けて関係者 } \\
\text { が連携する検討WGシステムを要請 }\end{array}$ & $\begin{array}{l}\text { 組織 } \\
\text { マネジメント }\end{array}$ & $\begin{array}{l}\text { 技術的検討を行う木材WGを設置した } \\
\text { (県・市・JR・木材関係者・設計者) }\end{array}$ \\
\hline & $\begin{array}{l}\text { 市民への計画内容の情報公 } \\
\text { 開の検討 }\end{array}$ & $\begin{array}{l}\text { ジポジウム開催によって市民へのアカ } \\
\text { ウンタビリティ果たした }\end{array}$ & $\begin{array}{l}\text { コミュニテティ } \\
\text { マネジメント }\end{array}$ & $\begin{array}{l}\text { 市民活動グループへの参画呼びかけを積極 } \\
\text { 的に行った(県・市) }\end{array}$ \\
\hline \multirow{2}{*}{$\begin{array}{l}\text { 第3ステージ } \\
\text { 実施設計段階 } \\
\text { (2002〜 } \\
\text { 2004年) }\end{array}$} & $\begin{array}{l}\text { 市長交代によるD会議存続の } \\
\text { 危機への対応 }\end{array}$ & $\begin{array}{l}\text { 市民活動,周辺まちづくりも含めた } \\
\text { 議論の場としてD会議を機能させた }\end{array}$ & $\begin{array}{l}\text { 組織 } \\
\text { マネジメント }\end{array}$ & $\begin{array}{l}\text { 内部ミーティングを重ねチームとして情報 } \\
\text { と知識共有化を図った(県・市・設計者) }\end{array}$ \\
\hline & $\begin{array}{l}\text { 市民と設計者との連携方法 } \\
\text { の検討 }\end{array}$ & $\begin{array}{l}\text { 課外授業へ参加し子供や事業関係者 } \\
\text { との交流を支援した }\end{array}$ & $\begin{array}{l}\text { コミュニティ } \\
\text { マネジメント }\end{array}$ & $\begin{array}{l}\text { 杉コレクション開催へ向けての企画·運営 } \\
\text { の協力により信頼関係を構築した } \\
\text { (市・木材関係者・設計者) }\end{array}$ \\
\hline \multirow{2}{*}{$\begin{array}{l}\text { 第4ステージ } \\
\text { 施工維持管理 } \\
\text { (2004 } \\
\text { 2008年) }\end{array}$} & $\begin{array}{l}\text { 県・市共同から市主催への移 } \\
\text { 行検討 }\end{array}$ & $\begin{array}{l}\text { 会議継続によって,県・市・JRの協力 } \\
\text { 体制を維持した }\end{array}$ & $\begin{array}{l}\text { 組織 } \\
\text { マネジメント }\end{array}$ & $\begin{array}{l}\text { 職員交流システムにより担当者のマネジメ } \\
\text { ントスキル向上を図った(県・市) }\end{array}$ \\
\hline & $\begin{array}{l}\text { 市民による駅前空間の利活 } \\
\text { 用の促進方法の検討 }\end{array}$ & $\begin{array}{l}\text { 駅前利活用WG開崔により市民の利活 } \\
\text { 用二ーズを設計変更に反映し参画機会 } \\
\text { を促進した }\end{array}$ & $\begin{array}{l}\text { コミュニティ } \\
\text { マネジメント }\end{array}$ & $\begin{array}{l}\text { 市民自らが駅周辺の維持管理活動ができる } \\
\text { 環境づくりをサポートした(市・設計者) }\end{array}$ \\
\hline
\end{tabular}


実現化へ向けて関係者が一同に会する議論の場としてD 会議を位置づけると共に，専門的技術的検討の場となる デザインWGと市民代表による議論の場として街なか委 員会の設置を要請し, 県・市担当者はその要請に応えて いる. 第2ステージでは, 駅舎と高架構造物, 駅前広場 の一体的整備の検討が主題となり, 各々 JR, 県, 市の事 業所管の枠を越えて連携させるために, 関係者共同の木 材WGの設置を要請し, 各事業間の共通テーマである地 場産杉材利活用の技術的検討の場として機能させた．ま た標準設計に拘るJRに対しては, 標準設計外の高架構造 物設計によるコストダウン手法を提示することで, JRと の協力体制を固めることとなった。

第3ステージでは，地域個性を表す木を活かしたまち づくりを実践するために駅前広場や街路整備に関する 県・市事業を連携させ，共通設計仕様書を作成するなど， 複数事業の一体性確保を図っている. また木材利用を通 じて, 事業関係外にいた木材関係者や建築士会等に木材 WG等を通じて参画機会を促進する等, 関係者の有機的 な連携を図っている．第4ステージでは，完成したイン フラをストックとして駅周辺の民有空間における景観 コントロールを誘導することを戦略的に捉え, 設計者で ある建築士会とのWSや市民団体, 地権者間の勉強会一 のD会議委員や専門家を派遣することを要請し, 市は景 観計画と連動した建築作法書づくりや市民団体の維持 管理活動を積極的に支援することとした.

このように，D会議は中心市街地活性化という目標像 を実現するために, プログラム戦略を立案し, 関連複数 事業を稼動させるとともに, 各事業相互を有機的に結び つけ強化させる役割と機能を果たしてきたといえる.

\section{3.「複数事業の総合 · 統合」に関してD会議の果たし た役割}

目標像を実現するために抽出された複数のプロジェ クトを相互に連携させる機能に対して，D会議が対応し た内容をTable 3に整理する. Table3の左から第1欄には事 業段階, 第2欄にはD会議が直面した課題, 第3欄には課 題を解決し複数事業の総合・統合化のためにD会議が実 施したマネジメント内容，第5欄にはD会議からの要請・ 指示に基づく関係者等の対応を整理した (第4欄は後述 する).

プログラム戦略を具現化するために，駅舎建設. 鉄道 高架. 駅前広場や道路等の県・市・JRが主体となる複数 事業を連携させ，共有するコンセプト設計を各事業に反 映し，かつ地区全体の空間デザインに一貫性を確保する ために，D会議は，第1ステージでは，県・市担当者に全 国での事例研究を指示し，連携体制の問題点に対処する ための体制づくりとしてD会議およびデザインWGの設 置を要請した. 第2〜3ステージにおいては, JRと市の離
脱危機に対して，一体的整備の必要性を訴え，県・市担 当者とともに関係者協議を重ね，JRおよび市の内部組織 体制と整合する形で駅舎設計者の設計監修への配置や市 委託コンサルと設計者のJVによる設計体制などマネジメ ント・システムを維持継続することに努めた.

第4ステージにおいては, 駅周辺の景観コントロール戦 略に基づき，公共施設のみならず民有空間の建築物等に ついても一体的な誘導を図るため, 建築士会や木材関係 者との連携を強化するためのWS開催等を要請, 地元発意 の景観ルールづくり提言をアドバイスした. 建築士会は これに基づき, 建築作法書を作成し市長へ提言している.

このようにD会議は, 駅周辺地区整備における官民関 連事業の相互連携と一体性を確保寸るために, 複数事業 の調整等の総合的・統合的なマネジメントの役割を果た してきたことが確認できる.

\section{4.「SC醸成を意図した市民等の活動支援」に関してD 会議の果たした役割}

SC醸成を意識して, 市民の公共空間の利活用につなが る市民等の活動に対する支援としてD会議が対応した内 容をTable 4に整理する. Table4の左から第1欄には事業段 階，第2欄にはD会議が直面した課題，第3闌には課題を 解決しSC醸成への活動支援としてD会議が実施したマ ネジメント内容，第5欄にはD会議からの要請・指示に基 づく関係者等の対応を整理した (第4欄は後述する).

$\mathrm{D}$ 会議は発足当初から公共施設等のハード面整備のみ ならず，市民の参画促進と将来の利活用が中心市街地活 性化一向けての重要な課題として捉え，市民と事業者と の交流を積極的に支援する役割を担ってきた．特に第2 ステージ以降は，シンポジウムの定期的開催によるプロ ジェクト進捗状況の市民への情報公開を要請し, 県・市 の共同で4年連続シンポジウムを開催し, 事業目的と進 捗状況，市民意識の向上に努めた.

また第3ステージ以降では，次代を担う子供たちへの

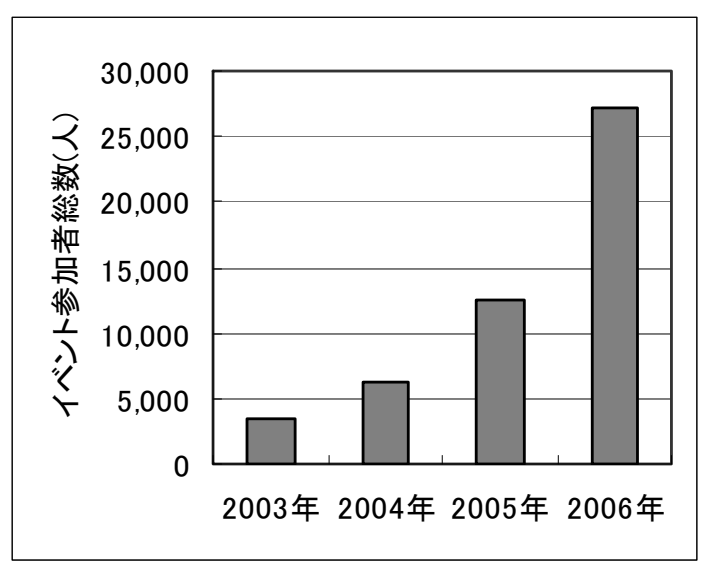

Fig 4 イベント参加者数の推移 


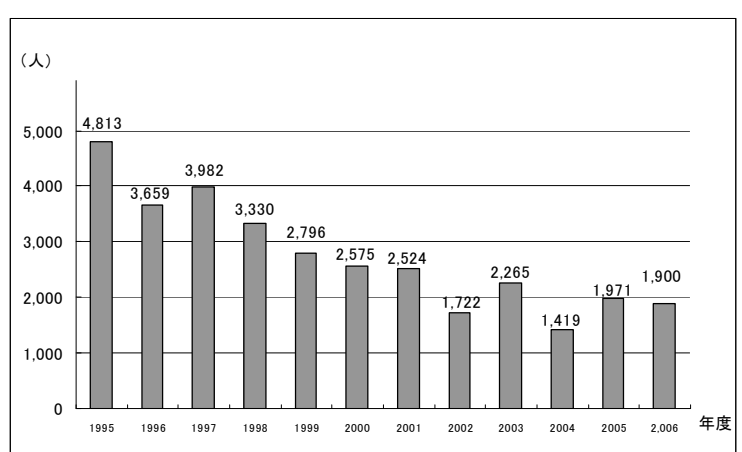

Fig 5 中心市街地歩行者数(平日 - 同一地点)

Table 5 日向地区視察者の推移

\begin{tabular}{|c|r|r|}
\hline 年度 & 視察団体数(組) & \multicolumn{1}{c|}{ 視察者数(人) } \\
\hline 2003 年度 & 13 & 83 \\
\hline 2004 年度 & 14 & 128 \\
\hline 2005 年度 & 23 & 578 \\
\hline 2006 年度 & 60 & 1239 \\
\hline 2007 年度 & 38 & 885 \\
\hline
\end{tabular}

まちづくり学習へも取組むことを提案し，県・市・デザ イナーが協力し，地元小学生に対する課外授業を計4回 開催している.この課外授業を契機として子供たちの関 心が街へ向けられるとともに, 家族や学校関係者もプロ ジェクト推進へ積極的な協力を促寸こととなった. さら に第3〜4ステージ以降では, プロジェクトの進展に伴っ て, 設計〜施工段階での駅前広場, 街路, 交流広場に対 して市民団体, 市民代表, 設計者, 学識者の参画による 駅前空間利活用WGが開催され，市民側の利用ニーズを設 計内容一反映させるプロセスを経ている. この結果, 施 設完成後は, 市民主体の企画運営による商業街区での各 種イベント開催(十五夜祭り, 街なかハロウィン等), 木 材関係者の協力による地場産杉を活かしたストリート ファニチャ製作とそのメンテナンスへの市民参加, 街育 てグループの結成等の活動が生まれ，イベント等による 集客数が増加し(Fig.4), 市民らは駅前空間に愛着を持っ て，市民活動に参画するようになった。

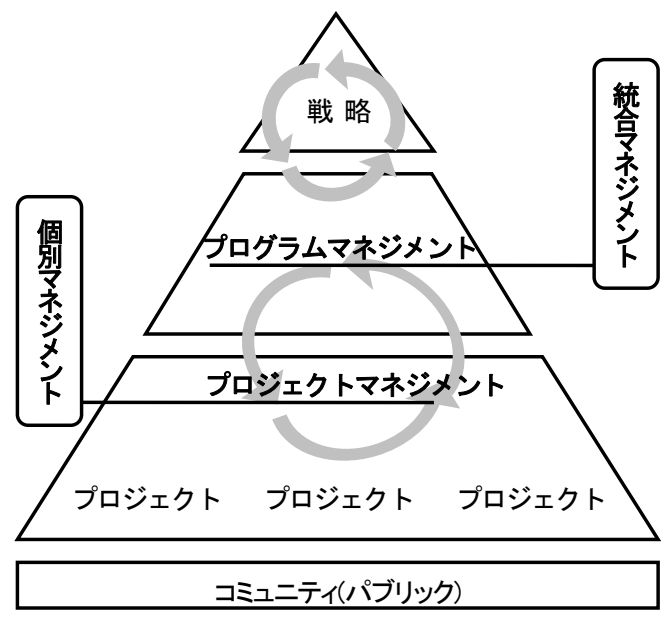

Fig.6 P2M タワーによる体系概要 ${ }^{15)}$
このように，D会議が当初から意図していた良質な公 共空間整備と連携した市民のSC醸成の育成への積極的 な支援が効果を挙げているといえる. なお，中心市街地 における歩行者交通量については, Fig.5に示すように商 店街の空洞化が顕著となった1990年初頭から減少傾向 を示していたが，新駅開業前(2008年)頃から徐々に歩行 者が増加傾向にあり, 微増ではあるが街なかに人々が戻 りつつある。

またTable 5に示すように日向市駅開業前から年間10組 前後の視察者が本地区に訪れていたが，新駅開業前年か ら急激に県外からの視察者が増加しており, 駅開業後も 500〜800人の視察者が来訪している. これらは，日向プ ロジェクトの目的である中心市街地活性化が進展してい ることを示している.

以上より, SC醸成, 中心市街地活性化に対して, D会 議の支援が機能したことと判断できる.

\subsection{P2MからみたD会議の機能}

複数のプロジェクトを統合的に遂行, 管理するPM体系 の中に，「プロジェクト \&プログラム・マネジメント( 以下, Project \&Program Management: P2M 略記する) ${ }^{15}$ 」がある. Fig.6の P2Mタワーに示されているように, P2M 体系は, 複数の個別プロジェクトへのマネジメント項目( 統括・タイム・組織・コミュニティ等に関する管理)の上 位に全体を統合するプログラムマネジメントが存在し, 全体の戦略・統括を管理するものである.

Table 2の左から第3欄に整理したD会議が目標像明確 化·戦略立案のために実施したマネジメント項目は, P2M における「統合マネジメント」6項目のうち戦略・組織・ 統合マネジメントに該当寸る. Table 3の左から第3欄に整 理したD会議が複数プロジェクトの総合・統合のために 実施した「個別マネジメント」11項目のうち統括・タイ ムマネジメントに該当する. またTable 4の左から第3闌に 整理したD会議がSC醸成を意図した活動支援のマネジメ ント項目は「統合マネジメント」のコミュニティマネジ メントと「個別マネジメント」の組織マネジメントに該 当している.

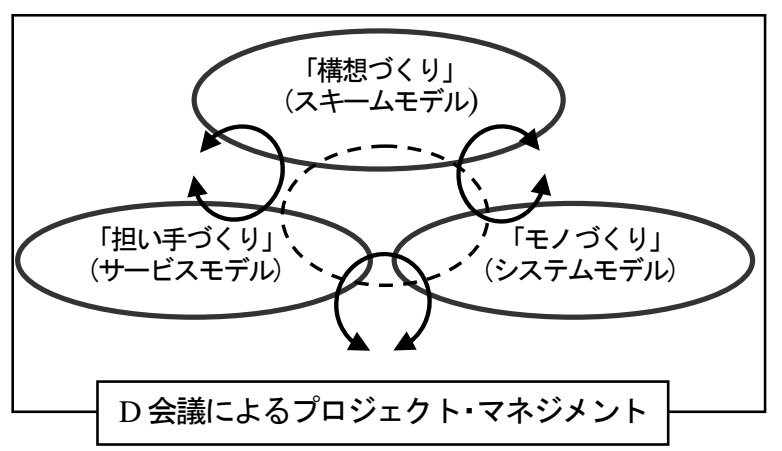

Fig.7 地域再生のためのP2M循環応用モデル 
Table 6 D 会議における機能と評価結果

\begin{tabular}{|c|c|c|c|}
\hline $\begin{array}{l}\mathrm{P} 2 \mathrm{M} \\
\text { モデル }\end{array}$ & $\begin{array}{c}\text { 構想づくり(スキームモデル)」 } \\
\text { 構想をくつりあげる段階にこプログ ラムの全 } \\
\text { 体目標に基づき, 複数プロジ ェ外のシナリ } \\
\text { オに展開し, その実現可能性を検討する }\end{array}$ & $\begin{array}{c}\text { 「モノづくり(システムモデル)」 } \\
\text { 従来型プロジ ェ外のモデルに相当し, 構想づ } \\
\text { くりの目標に基づいて所定の個別プロジ ェク } \\
\text { トの一貫した時間管理により具現化する }\end{array}$ & $\begin{array}{l}\text { 「担い手づくり(サービスモデル)」 } \\
\text { モノづくりによる成果を利用して担い手を } \\
\text { 育成し, ソフト・知識・サービスを織り込 } \\
\text { んだ独自の新しい地域価値を生み出す }\end{array}$ \\
\hline 機能 & $\begin{array}{l}\text { 1. D会議は, 目標像を明確化し, その具現 } \\
\text { 化のためのブログラム戦略となる「構想づ } \\
\text { くり」を行った. } \\
\end{array}$ & $\begin{array}{l}\text { 2.D会議は, 複数の公共プロジ ェ外を総合・ } \\
\text { 統合した「モつづくりとして機能した. }\end{array}$ & $\begin{array}{l}\text { 3.D会議は, SC醸成を意識して市民の公共 } \\
\text { 空間の利活用につなげる「担い手づくり」 } \\
\text { を実践した. }\end{array}$ \\
\hline $\begin{array}{l}\text { P2Mマネジ } \\
\text { メント項目 }\end{array}$ & $\begin{array}{l}\text { 「戦略マネジメント」 } \\
\text { 「統括マネジメント」 }\end{array}$ & $\begin{array}{l}\text { 「統括マネジメント」 } \\
\text { 「タイムネジメント」 }\end{array}$ & $\begin{array}{l}\text { 「組織マネジメント」 } \\
\text { 「コミュニティマネジメント」 }\end{array}$ \\
\hline
\end{tabular}

P2Mは「スキームモデル(構想化)」,「システムモデル( 構築)」,「サービスモデル(成果価值の再利用や更なる付 加価值追求)」の3種類のプロジェクトモデルがあり, これ らの組み合わせの相乗効果でプログラムの価值の最大化 を目指している. そしてFig.6に示寸ように, 個々のプロジ エクトを統括するための全体戦略とプログラムが描かれ, 総合的なマネジメントがなされる.

ただし，P2M体系は複数のプロジェクトを連動・統合 するシステムではあるが，それを地域づくりのための公 共事業に適用するにあたっては，公共性，透明性，主体 の多様性等の公共事業特有の性質が考慮される必要があ ろう。これらの性質を考慮すれば，地域再生へ向けた公 共事業のためのP2Mを以下のように定義できよう.

プログラム : 地方自治体が地域づくり施策の目標達成 のために具現化, 実施する複数のプロジェクトが有機 的に結合された事業パッケージ.

P2M : 物的, 人的地域資源を活用しながら, 複数の公 的プロジェクト間の全体統合を行うことを通じて，プ ログラムの目標を達成するマネジメント手法.

このように定義すればTable 2, Table 3 およびTable 4の 左から第3欄でD会議が実施マネジメント項目は第4欄の P2Mマネジメント項目に対応することが確認でき，民間 企業活動を想定するP2Mをまちづくりに読み替えること が可能となろう。具体的には，Fig. 6に示すように，スキ 一ムモデルをまちづくり戦略となる「構想づくり」に, システムモデルを複数のプロジェクトを統合させ一貫性 を持たせた「モノづくり」として置き換えることが可能 となる. またサービスモデルについては, 整備後の公共 空間の価值を高める市民活動を育成する「担い手づくり $」 と し て$ 対応でき, 相互が連携し循環するシステムとな る. 一般的なPMは企業の財務的成功を最終目標とする. これに対して, 地域づくり PMはエンドューザーである多 様な利用者 (市民)を取り込みながら推進し, 豊かな生活 環境の向上を実現することが最終目標として求められる. これは公共事業の特徴であることが理由である.

$\mathrm{D}$ 会議の果たした $3 つ の$ 機能とP2Mマネジメント項目 を上記の3モデルで再整理したものがTable 6である.この ことより, $\mathrm{P} 2 \mathrm{M} の$ 観点から以下のように考察できる

1) 約10年間に亘る日向プロジェクトにおいては，第1ス
テージでは，議論と調整の場となる「日向地区・都市 デザイン会議(D会議)」の組織化とチーム編成と戦略プ ログラムの策定, 第2ステージでは, 情報公開による計 画コンセプトおよび事業手法についての市民合意の形 成，第3ステージでは，D会議と市民との交流・対話等 による事業目標の共有化, 第4ステージでは, 市民・行 政・専門家の間の情感共有と目標達成意欲の向上，人 的ネットワークの拡大という, 専門家中心の活動から 市民活動へのプロセスに展開されたことが認められた. このことは当初にプログラムされた地域再生のための 三位一体事業の目標が達成されつつあり, P2Mの視点 に照らせば「構想づくり(スキームモデル)」が機能し たと考察できる.

2) D会議は複数のプロジェクトの空間的管理および時間 的管理の中心を担ったが，アンケート調査の分析から その一貫性のある空間づくりに対する, 役割と活動は, 事業関係者，市民や来訪者等から高く評価されている ことが確認できた. このことから，P2Mにおける「モ ノづくり(システムモデル)」が機能したと考察できる.

3) プロジェクトの進捗に伴い第 3, 第4 ステージにおい て，まちづくり参画者のネットワークは事業関係者 (行政および専門家)から市民グループや木材関係者， 一般市民へと拡がり, 主体的にイベント開催や維持管 理活動等が展開されるようになった。 これには, 関連 委員会委員がプロジェクトへ参加したことが契機と なって各々の意識が変化しまちづくり活動等を展開 したことが大きく影響していることを確認できた.

このことは, 本プロジェクトのインフラ整備におい て実践されてきた空間的管理, 時間的管理による総合 的・統合的なプロジェクト・マネジメントが地域への 誇りや愛着等を増進させる SC の醸成にとっても有効 に機能したことを示唆するものであり，P2M におけ る「担い手づくり(サービスモデル)」が実践されたと 考察できる.

\section{4. まとめ}

本論の内容を要約すると以下の通りである. 
(1)まちづくりや地域再生を目標とする複数の公共事業 を統括する事例として, 日向市駅周辺のまちづくり事 業推進のために設置した「日向市都市デザイン会議( D 会議)」が実施した監理(マネジメント)の実施内容を整 理した.

(2)そのマネジメントの内容をプロジェクト \& プログラ ム・マネジメント(P2M)の視点から, 機能-1:地域再生 をめざしたまちづくり目標像を明確化し，その具現化 のための戦略の立案機能, 機能-2:複数の公共プロジェ クトの総合・統合機能，機能-3:SC醸成を意困した市民 の公共空間の利活用につなげる駅広委員会の開催等の 活動支援機能を評価した，その結果，D会議は，機能 -1に関しては「戦略マネジメント」と「統括マネジメ ント」，機能-2に関しては「統括マネジメント」と「タ イムマネジメント」，機能-3に関しては「組織マネジ メント」と「コミュニティマネジメント」を担うとと もに，それらが機能したことを確認できた。

(3)複数の公共事業のマネジメントの上記3つの機能と P2Mの機能を対照させると，「構想づくり(スキームモデ ル」「モノづくり(システムモデル」「担い手づくり(サービ スモデル)」として捉えることが可能と判断できる. SC醸成の観点に着目すれば今後においては，「担い手 づくり」が重要になるものと考えられる.

\section{参考文献}

1) 大阪大学NPO研究情報センター (2005), 日本のソーシャ ル・キャピタル」。
2) 土木学会誌 (2005), 「特集/景観去と土木の仕事」, 第90巻第2号.

3) 新谷大輔 (2005), 「産業集積とソーシャル・キャピタル」, 日本NPO学会第7回年次大会発表論文.

4) 内閣府国民生活局市民活動促進課 (2002),「ソーシャル・キャ ピタル : 豊かな人間関係と市民活動の好循環を求めて」,

http:/wwwnpo-homepage.go.jp/data/report9_1.html,[2010.02.20 ]

5) 演李三洙他 (2005), 「大都市都心部における地域類型別工 リアマネジメント推進組織に関する研究」, 都市計画論文 集, No.40-3,pp.481-486.

6) 磯崎正晴 (1991),「土木技術者のためのデザイン・マネジ メント」, 山海堂.

7) 国土交通省土地・水資源局 (2008),「エリアマネジメント推 進マニュアル」.

8）東海林孝男他 (2007),「都市基盤事業と連動した都心息の エリアマネジメントの検討」,日本建築学会大会学術講便 概集, No.7104, pp.239-242.

9) 小林敏樹 (2007), 「改正中心市街地活性化法にもとづくタ ウンマネージメント組織の形成」, 日本建築学会大会学術 講演便概集, No.7105, pp.243-246.

10) 小林重敬 (2008), 「エリアマネジメント」, 学芸出版社

11) 宮崎県日向土木事務所 (2007), 「日向地区デザイン会議報告 書」.

12) 篠原修他 (2009), 「新・日向市駅」，彰国社

13) 日向市 (2006),「日向地区都市デザイン会議設置要綱」。

14) (財)udc (2007), 「市街地整備における景観事業推進のた めの新たな施策研究会提言書」 .

15) 日本プロジェ外祙メ恊会 (2007), 「新版P2Mプロジェクト \&プログラム・マネジメント標準ガイドブック, JMAM.

\title{
FUNCTIONAL EVALUATION OF HYUGA-CITY URBAN DESIGN COMMITTEE FOR PLURAL PUBLIC PROJECTS MANAGEMENT
}

\author{
Yoshihiko TSUJI $^{1}$, Tetsunobu YOSHITAKE ${ }^{2}$, and Chikashi DEGUCHI ${ }^{3}$ \\ ${ }^{1}$ Doctor Course, Interdisciplinary Graduate School of Agriculture and Engineering, University of Miyazaki \\ (E-mail: y-tsuji@atelier74.co.jp) \\ ${ }^{2}$ Dr. of Eng., Associate Professor, Civil \& Environmental Eng., University of Miyazaki \\ (E-mail: t.yoshi@cc.miyazaki-u.ac.jp) \\ ${ }^{3}$ Dr. of Eng., Associate Professor, Civil \& Environmental Eng., University of Miyazaki \\ (E-mail: deguchi@cc.miyazaki-u.ac.jp)
}

In city-center renovation, it is usual that several development projects including public and private facilities are employed. Furthermore, on the viewpoint of city-center revitalization, the promotion of the public utilization of these facilities is important. That is, the total management of development projects and approach to public is required. However, this management usually becomes difficult because the various organizations concerned are based on their own institutional systems. In Hyuga City, the railroad elevation, new station building, station parks, land re-adjustment, shop-concentration in shopping districts were executed in the city central area. The city established 'Hyuga City Urban Design Committee' to manage these projects. This paper analyzed and evaluated the roles and functions of the committee, based on the project records and questionnaire surveys. This paper revealed that the committee actually played the total management role well for these projects.

Key Words: Public Projects, Project Management, Urban Renewal, Social Capital 